\title{
OBSERVATIONS ON DAILY LIFE IN THE COMMUNAL TOWN OF LEOPOLI-CENCELLE
}

\author{
Notas sobre la vida diaria en la civitas de Leopoli-Cencelle
}

\author{
Giorgia Maria Annoscia \\ giorgia.annoscia@uniroma1.it \\ Sapienza Università di Roma. Italy \\ Fecha de recepción: 04/05/2017 \\ Fecha de aceptación: 07/06/2017
}

RESUMEN: La civitas de Leopoli-Cencelle, fundada por el Papa León IV (s. IX), está situada en las Montañas de Tolfa en el Norte de la Provincia de Roma. El sitio fue objeto de investigación arqueológica dirigida por el Departamento de Arqueología Medieval de Sapienza Universidad de Roma. El trabajo se centra en el análisis de unas 30 herramientas agrículas (hachas, azadas, hoces, podaderas) de la fase estratigráfica de la ciudad municipal (ss. XIII-XIV). La interpretación de los datos materiales de estas herramientas, conjugados con los datos que vienen de las fuentes escritas, de la iconografía, de las ciencias aplicadas a la arqueología, nos ofrece un amplio panorama sobre varios aspectos sociales del ciclo de la producción agrícola en Leopoli.

Palabras clave: Leopoli-Cencelle; Arqueología Medieval; Agricultura; Herramientas agrículas; Hierro.

ABSTRACT: The civitas of Leopoli-Cencelle, founded by Pope Leo IV ( $9^{\text {th }}$ cent.), is located in the Tolfa Mountains on the northern edge of the Province of Rome. The site has been the object of archaeological research directed by the Department of Medieval Archaeology at La Sapienza University of Rome. The paper focuses on the analysis of about thirty agricultural artefacts (hoes, sickles, billhooks and axes) originating from stratigraphic contexts corresponding to the town's communal facies $\left(13^{\text {th }}-14^{\text {th }}\right.$ cent.). The interpretation of the material properties of these tools, resulting from a synthesis of data from written sources, iconography, science applied to archaeology and the artefacts' contexts of recovery, allowed us to shed light on several social aspects of the agricultural production cycle at Leopoli.

Keywords: Leopoli-Cencelle; Medieval Archeology; Agriculture; Farming tools; Iron.

SUMMARY: 1. Figures. 2. Bibliographical References. 
"The work of a historian lies in constantly striving to make inanimate objects talk». With these words Gabriella Maetzke (1986, p. 267) explains why we examine artefacts $^{1}$. From the analysis of "small things», we aim to infer "the big picture», such as the historical and socio-economic context ${ }^{2}$. This holds true especially for objects that are -like working tools- characterised by morphological inertia, in that the relationship between usage and form takes precedence over aesthetic considerations. Indeed, these artefacts, in which people have for generations invested at least some of their ingenuity, required no further modifications ${ }^{3}$ once perfected through experience and adapted to the needs of the societies to which they attest. In addition, such functional -at times multifunctional- tools embody a high use value, being products that imply well coded technical and scientific knowledge. This proposition is particularly true of farming tools, considered almost a natural extension of human limbs ${ }^{4}$. The following is an analysis of about thirty agricultural artefacts (hoes, sickles, billhooks and axes) originating from stratigraphic contexts corresponding to the communal facies $\left(13^{\text {th }}-14^{\text {th }} \mathrm{c}\right.$.) of the civitas of Leopoli-Cencelle ${ }^{5}$, founded in the early Middle Ages. These artefacts have thus far been studied ${ }^{6}$ only partially by Francesca Zagari (2005 and 2012) and Vasco La Salvia (2000a and 2000b). The re-interpretation of the material properties of these tools, resulting from a fruitful synthesis of data from written sources, iconographic comparisons, the contribution of science applied to archaeology and the artefacts' contexts of recovery, allowed us to shed light on several social aspects of the agricultural production cycle at Leopoli-Cencelle. For this purpose, following in the footsteps of Juan Antonio Quirós Castillo (2014a), storage systems ${ }^{7}$, anthracological, carpological and zooarchaeological records, as well as loci of transformation and management of agricultural and livestock resources have been taken into account. This was done with the aim of reconstructing a landscape that is no longer visible; a landscape that was experienced, shaped, transformed and perceived by the individuals and social groups that inhabited it and contributed to «writing" the history embodied in these farming tools and the spaces in which

${ }^{1}$ A shorter version of this paper («Vita quotidiana nella città comunale di Leopoli-Cencelle: gli attrezzi agricoli») was read at the $V$ International Medieval Meeting Lleida (Universitat de Lleida, 25-26 June 2015).

2 Giannichedda, 2006.

3 Parenti, 1994, pp. 112-118; Mannoni \& Giannichedda, 2003.

${ }^{4}$ Giannichedda, 2014.

${ }^{5}$ Stasolla, 2012. Ermini Pani \& Somma \& Stasolla, 2014.

${ }^{6}$ Martorelli et al., 1996.

7 On the storage of agricultural produce, and especially on the multifunctionality of silos, see Malalana Ureña \& Morín de Pablos \& Barroso Cabrera, 2013. Vigil-Escalera Guirado, 2013. 
they were stored ${ }^{8}$. An analysis of the agricultural fields cultivated by those peasants, and of associated social aspects, will be the focus of future studies. Such studies will aim to reconstruct the agricultural production cycle, since the landscape is an expression and a result of the joint action of the members of rural communities ${ }^{9}$.

Our story begins with the civitas of Leopoli-Cencelle, founded in the year 854 by Pope Leo IV (Le Liber Pontificalis, II, pp. 131-133) in order to defend and ensure the safety of the inhabitants of the Roman town of Centumcellae, presentday Civitavecchia, against Saracen raids: "from an urbanistic standpoint», the town represents "a rare, even unique case in many ways, if only for its definite founding date ${ }^{10}$. The site is located in the Tolfa Mountains, atop a hill 168 m.a.s.l on the northern edge of the Province of Rome, a few kilometres from the Tyrrhenian coast (Illustration 1). For the past twenty years or so, the site has been the object of archaeological research, promoted and directed by the Department of Medieval Archaeology at La Sapienza University of Rome (first under the scientific direction of Letizia Ermini Pani and later under Francesca Romana Stasolla). Since its inception, the project has also involved the D'Annunzio University of Chieti ${ }^{11}$ and - for the first six years - of the École Française de Rome ${ }^{12}$.

The excavations brought to light part of the settlement, still surrounded by its $740 \mathrm{~m}$ of massive defensive walls with seven towers and three gates (Illustration 2). These structural elements were intended to be deterrent and threatening, but also monumental and imposing. Defence - the leit motiv - is expressly stated in the official monumental inscription originally placed over the town's main gate, the eastern gate. This inaugural inscription, dating back to the $9^{\text {th }}$ century, like the town itself, seems almost to have aimed at consecrating the founding of the town ${ }^{13}$.

The available documents allowed us to reconstruct the historical vicissitudes of this town, characterised by political instability. Indeed, political instability manifested itself in Leopoli-Cencelle as early as the town's first attempt at gaining independence from the Roman Church (late $11^{\text {th }} \mathrm{c}$.). Despite its aspirations for independence, Cencelle repeatedly fell under the aegis of the Church. The town was briefly reconquered in 1107 by Pope Paschal II, of whom it is said "copiis munivit et armis» (Le Liber Pontificalis, II, pp. 298-299) and later returned to Clement III by

${ }^{8}$ For a comparison with other European regions, see Comet, 1992; Del Sweeney, 1995; Brufal Sucarrat, 2013.

9 I refer to the agrarian archeology studies in Spain. See Barceló, 1988; Barceló, 1995; Kirchner, 2010; Quirós Castillo, 2014.

10 Ermini Pani, 2012.

11 Somma, 2014.

12 Bougard et al., 1996; Bougard \& Cirelli, 2014.

${ }^{13}$ Ermini Pani \& Guerrini, 2014, p. 15. 
emperor Henry VI in $1189^{14}$. As a defensive and strategic bulwark of Papal power in defence of the territories of northern Latium, part of the Patrimonium of the Roman Church, the area was claimed between the $13^{\text {th }}$ and $15^{\text {th }}$ centuries by a number of contenders. Among them were Viterbo, to which the town of Cencelle submitted in $1220^{15}$ in order to repay its debt to the city of Corneto (present-day Tarquinia); the Apostolic Camera, with recurring episodes linked to territorial defence operations ${ }^{16}$; and Corneto itself, as can be deduced from the oath (sequimento) that the Mayor of Cencelle took before the representatives of the commune of Corneto first on 2 August $1307^{17}$, and then again - under the same conditions - in $1362^{18}$.

These countless vicissitudes resulted from the desire of local powers to exercise political and economic control over the fertile agricultural land surrounding the civitas. The high productivity of the region is reflected not only in the presence of numerous country villae ${ }^{19}$ from the Classical era but also in the common expression "terre da pane ${ }^{20}$ (bread lands), used to describe the area in question, dominated by the favourable geoeconomic position of Corneto, the «warehouse of Rome's abundance ${ }^{21}$. This area linked the rich, wheat-producing agricultural hinterland with the maritime trade routes along the Ligurian basin, reaching as far as Catalonia and Aragon, witnessed by both commercial contracts and material culture ${ }^{22}$.

Indeed, the material evidence found in Cencelle -glazed ceramic tableware as well as glass and metal dishes- speaks of a town in full economic development; a town that, through Corneto ${ }^{23}$, was part of a dense trading network. Cencelle imported ceramic artefacts (Illustration 3) originating from along the shores of much of the Thyrrhenian sea, as evidenced by the recovery of amphorae from Cilento, from Liguria (Savona archaic sgraffito) and even from Tuscany (Pisa archaic majolica) and from Spain (mature Valencian lustreware) ${ }^{24}$.

14 Fumi, 1884, doc. 38, pp. 38-39.

15 Calisse, 1936, XV.1, pp. 754-756; Toti, 1993, pp. 109-110.

16 In 1264, Urban IV sent letters to a number of Communes, including Cencelle, calling on them to resist Manfred, who was allied with Peter of Vico (MGH, Ep., II, n. 624, p. 616).

17 Calisse, 1936, XVIII.1, pp. 770-773.

18 Archivio Storico Comunale di Tarquinia, Tarquinia, Italia, cartella XIV-B, 2, n. 7; Calisse, 1936, XVIII-XIX, pp. 770-774.

19 Nardi Combescure, 2002; Vallelonga, 2012.

${ }^{20}$ La «Margarita Cornetana», doc. 19, p. 68; doc. 82, p. 109; doc. 96-97, p. 116; Cortonesi, 1988 a, p. 40.

${ }^{21}$ Brief, Alexander VI (Archivio Storico Comunale di Tarquinia, Tarquinia, Italia, Ref. 9-317, f. 126r); La «Margarita Cornetana», doc. 586, pp. 432-433, a. 1499.

${ }^{22}$ Cirelli, 2002; Abulafia, 2009; Palermo, 2009; Stasolla, 2009.

${ }^{23}$ Casocavallo \& Camardo, 2005; Cataldi \& Casocavallo, 2009.

${ }^{24}$ Stasolla, 2009; Annoscia, 2012. 
The parallel reading of documents allows us to define the essential role played by the port of Corneto, a harbour frequented by Ligurians (first contract with Genoa in 1177) ${ }^{25}$, Tuscans (first contract with Pisa in 1173$)^{26}$, as well as by merchants from southern Italy and from Spain. An important piece of evidence illustrating the existence of trade ties between Corneto and Spain is the privilege by which, in 1204, Peter II of Aragon exempted the inhabitants of Corneto visiting his territories from any tax and guaranteed them personal safety ${ }^{27}$. Corneto's strong trade ties outside of the control of Rome resulted in recurrent conflicts with the city of Rome, which believed it should maintain its supremacy in the maritime district of which Corneto was part. Thus, for example, a certain amount of wheat or of fodder was expected to reach Rome to guarantee supplies to the city ${ }^{28}$; since this did not always occurr, Corneto was often subjected to fines ${ }^{29}$ or even military reprisals ${ }^{30}$.

The urban decline ${ }^{31}$ of Leopoli-Cencelle (due also to the violent earthquake of 1349) began following the discovery of alunite in the Tolfa Mountains around the middle of the $15^{\text {th }}$ century; an event that transformed the landscape, which was subdivided into estates to accommodate mineral production and marketing needs ${ }^{32}$.

Giovanni Battista Cingolani, in his 1696 "Catasto delle Tenute di Allumiere» (Registry of Alunite Mine Holdings) ${ }^{33}$, makes specific mention of a "Tenuta di Cincelli» (Holding of Cincelli), on which the Camera Apostolica had the right to pasture cattle («ius pascendi»). In this document (Illustration 4), Leopoli-Cencelle is portrayed in a particularly meaningful figure accompanied by a legend that reads, "Cincelli oggi diruto» («Cincelli now in ruins»).

From an architectural standpoint, the structural remains can, for the most part, be attributed to the communal urban plan of the "civitas Centumcellensis» (i.e., late

${ }^{25}$ La «Margarita Cornetana», pp. 144-145.

${ }^{26}$ Archivio di Stato di Siena, Siena, Italia, Atti Pubblici, vol. XXIII, n. 51, a. 1173.

27 La «Margarita Cornetana», doc. 318, pp. 240-241.

${ }^{28}$ La «Margarita Cornetana», doc. 19, a. 1283, pp. 68-69; doc. 82, a. 1304, p. 109; doc. 96. a. 1302 , p. 116 ; doc. 97 , a. 1302 , pp. $116-117$; doc. 98 , a. 1302 , p. 117 ; doc. 100 , a. 1302 , p. 118 ; doc. 125 , a. 1293 , p. 131 ; doc. 189 , a. 1294 , p. 159 ; doc. 282 , a. 1297 , p. 220 ; doc. 290 , a. 1299 , p. 225.

29 La «Margarita Cornetana», doc. 20, a. 1284, p. 69; doc. 241, a. 1294, pp. 194-195; doc. 243 , a. 1295 , pp. 196-197; doc. 248 , a. 1305 , pp. 199-203; doc. 249, a. 1296, pp. 203-204; doc. 283 , a. 1296 , pp. $220-221$; doc. 375 , a. 1309 , p. 289 ; doc. 378 , a. 1309 , pp. 291-292; doc. 393, a. 1310, pp. 302-303.

30 La «Margarita Cornetana», doc. 374, a. 1308, p. 288.

31 Jamme, 2005; Vallelonga, 2006.

32 Zifferero, 1996; Ait, 2010; Stasolla \& Di Nezza \& Doronzo, 2011.

${ }^{33}$ Archivio di Stato di Roma, Roma, Italia, Catasto Cingolani, Disegni e Piante, cart. 122, f. 211, tav. 16. 
$12^{\text {th }}-14^{\text {th }}$ c.). St. Peter's Romanesque church (sector VI, north-south orientation), which dominates the landscape from the hilltop, symbolically faces the new seat of civic power, the "palatium comunis» rising across the main street ${ }^{34}$ (Illustration 5). The church has three naves and a three-apsed, raised chancel that impressively juts out from the city walls. Beneath the church is a crypt, presumably an oratory-crypt.

The residential area $^{35}$ (sectors I and II), on the south-eastern slope of the hill, is dotted by terraced houses having a typically late-medieval flavour, where the dwellings and the blacksmith's workshop (faber) intermingle. Slightly further to the east (Illustration 6), bordering on the town's main gate, where the road that leads to the political and religious centre of Leopoli-Cencelle-"via carraia»-originates, an artisans' quarter (sector III, studied by the École Française de Rome) ${ }^{36}$ hosts workshop (unit $\mathrm{H}$ ) for the processing of metal, mainly iron (Illustrations 7 and $14-\mathrm{H}$ ). This is the sector that, more than others, appears to be associated with extra-urban activities (such as agriculture), perhaps by virtue of its proximity to the main gate. Facilities for the storage of food, tool sheds and working areas all provide material evidence to the kaleidoscopic social reality described in the documents.

The analysis of the archaeobotanical and archaeozoological record contributed significantly to the reconstruction of the agrarian landscape of the medieval civitas. The anthracological and carpological remains ${ }^{37}$ were relatively abundant, and belonged to diverse species, and good quality cultivars. They were found to belong to 16 plant taxa, of which 10 were cultivated species (65\% seeds of wheat, along with lesser cereals such as barley, as well as red pea and other legumes). These remains confirmed that the agriculture of Leopoli-Cencelle was capable not only of providing sustenance to the inhabitants of the town, but also of exporting, as would befit an agrarian economy.

The analysis of charcoal fragments was mostly characterised by evidence of the presence of wood-eating organisms - organisms that only affect parts of the plant that are no longer vital - suggesting that the town's inhabitants used deadwood almost exclusively. The most abundant taxon $(77 \%$ of the charcoal fragments examined) was Quercus sp. deciduous group. Its frequent presence (54\%) in unit $\mathrm{R}$ of sector III, identified as an animal shed, strongly suggests that oak wood was employed in carpentry, toolmaking and the making of equipment for the rearing and management of livestock, such as feeding troughs and storage solutions for fodder.

\footnotetext{
34 Somma, 2014.

35 Martorelli, 2012; De Minicis, 2012.

36 Bougard et al., 1996; Bougard \& Cirelli, 2012.

${ }^{37}$ Savelli \& Larocca, 2012.
} 
Leopoli-Cencelle was endowed with vast uncultivated areas of woodland. These forests were mentioned in the early medieval topos ${ }^{38}$ of the foundation of Cencelle: a forest (silva) that supplied the inhabitants with timber, but that was also abundant in game, as corroborated by the archaeozoological analyses ${ }^{39}$ performed on the remains of deer, wild boar and roe deer attesting to widespread hunting. This also allowed the community of Cencelle to pay the "exenium venationis» ${ }^{40}$. There is therefore no doubt that, in the spatial arrangement of crops, the vast domain of sowed crops occupied the external sector, along with the grazing grounds, the maquis and the woods ${ }^{41}$.

This agrarian landscape was tamed by the peasants -individuals and social groups that are almost «invisible» in the sources. They were the "motor» of the agrarian production cycle, and an echo of their presence, albeit faint, lingers in the technical equipment. The study of such equipment sheds light on the hardships associated with work in the fields, on the threshing floor, in the barn and in the granary, evoking an image, a gesture, a snapshot. These endless moments of everyday agrarian life also materialise in the rich heritage of figurative art, both monumental and miniature ${ }^{42}$. With the necessary caution owing to the complexity of iconographic transmission processes, these works of art may be said to often illustrate the different cyclical phases of work in the fields as they get repeated through seasons and months, with precise attention to specific tasks, techniques and tools. Coeval iconography is thus a primary source for the study of tools. It contributes to our knowledge of both the shapes of the tools - as it also portrays the wooden components that have not been preserved - and of their usage, helping reconstruct the so-called "archaeology of gesture».

About thirty farming tools ${ }^{43}$ (Illustration 8) were found at Leopoli-Cencelle or, to be exact, thirty iron heads, or blades of tools. Admittedly, it is a meagre sample (1\% of the entire sample of metal artefacts). The tools are almost frugal but are functional and effective. Their plain, austere morphology renders these tools almost indispensable, and bears testimony to their use value, as do the numerous thefts of ferramenta (iron tools) reported in the texts ${ }^{44}$. Being forced to part with them, as in

38 "Moreque bestiarum [...] per opaca silvarum montesque incognitos sua domicilia populus qui relictus ab eis fuerat dedicavit» (Le Liber Pontificalis, II, pp. 131-133).

39 Minniti, 2012.

40 Jamme, 2005, pp. 357-358, a. 1334.

${ }^{41}$ Cortonesi, 1988b.

42 Guidotti, 1981; Mane, 1991; Castiñeiras González, 1991; Mane, 2006.

43 Sogliani, 1995; Tramontana, 2000.

${ }^{44}$ The theft of iron tools, repeatedly referred to in the Compositiones del Patrimonio, seems to underscore the value of these objects; objects that were clearly far from being affordable by everyone (a. 1359, theft of a ploughshare, a spade and other goods), Cortonesi, 1988a e 1988b. 
cases where tools had been placed somewhere together, or having regrettably lost them, must have represented a considerable loss for the legitimate owner ${ }^{45}$.

As for the contexts of recovery, one group of tools ( 2 hoes, 3 billhooks, 1 sickle and 2 axes), $28 \%$ of the sample, was found in a storeroom-granary in the eastern quarter of Cencelle (sector III), where 2 hoes, 1 billhook, 1 scythe and 1 sickle were also found. The latter were found in primary deposition, as they were sealed by the sudden collapse of the structures during a big fire that appears to have struck not only the house (unit A) but also the granary (unit B) in the late $13^{\text {th }}$ century, leaving traces in the charred plant remains as well. The rest of the artefacts had been buried following the abandonment of the site (south-eastern quarter, sector II) or due to the raising of the ground level (inside the St. Peter's basilica, sector VI).

Some of the tools in question served to work the soil and «make it docile» (5 hoes); others were used to harvest wheat and other crops ( 1 scythe and 13 sickles); prune trees and vines (11 billhooks); or fell trees and cut large branches ( 2 axes).

Hoes (Illustrations 8 and 9) were used to loosen hard soils in order to dig deep, plough or facilitate ploughing ${ }^{46}$. The five specimens in question, three large ones $(25 \times 9 \mathrm{~cm})$, and two smaller ones $(15 \times 6 \mathrm{~cm})$ used for weeding ${ }^{47}$ are all of a single type, the ancient Roman hoe known as "Italian ligo» ${ }^{48}$, one of the most common in medieval Italy ${ }^{49}$, having a trapezoid blade with a quadrangular eye in the back, and a rounded edge. The back of the body is either straight or rounded.

Ripe, ready-to-harvest wheat-" cunctis messibus»- was cut using sickles ${ }^{50}$. The archaeological site of Leopoli-Cencelle yielded 13 specimens of such sickles (26-30 $\mathrm{cm}$-long blades) ${ }^{51}$ and one scythe (44-45 cm-long blade) ${ }^{52}$. Both the scythe and the sickles (Illustration 10) have narrow, pointed, crescent-shaped blades, with a flat

45 Baruzzi, 1987.

46 «Ligo, marra, marrone, zappa, instrumentum rusticum lato ferro, herbis ac radicibus evellendis, purgandoque agro et terrae fodiendae aptum» (Forcellini, 1940, s.v. Ligo).

47 The çappitello, mentioned in the sources along with the çappone, in the context of tilling. Cortonesi, 1988a, p. 49.

${ }^{48}$ White, 1967, ill. 17-18, p. 39; Vannini, 1985, especially ill. VIII/1-2, p. 371; La Salvia, 2005, p. 117.

49 As attested by a miniature painted in a Florentine workshop $\left(15^{\text {th }}\right.$ century), Virgilii opera (Biblioteca Medicea Laurenziana, Firenze, Italia, ms. Plut. 39. 7, f. 218r), or by another miniature included in the Breviarium fratrum minorum (ca. 1455-1460) illuminated by Sano di Pietro (Biblioteca Comunale degli Intronati di Siena, Siena, Italia, ms. X.IV.2, f. 2r).

50 «Ferramentum incurvum, seu aduncum, ad varios usus in re rustica: aliud est, quo segestes metuntur» (Forcellini, 1940, s.v. Falx).

51 Démians d'Archimbaud, 1980, ill. 457/2; Vannini, 1989, ill. XX/8, p. 471; Velluti, 1993, ill. 9/3, p. 181; Belli, 2002, ill. 16, p. 160; Ermeti \& Sacco \& Vona, 2008, ill. 4/18, p. 169; Vanni Desideri, 2009, pp. 231-232.

52 Démians d’Archimbaud, 1980, ill. 435/4; Gambaro, 1990, ill. XIII/55-56, p. 398. 
spine, ending with a narrow tang that extended into the wooden handle. As shown by the magnificent artistic representations, the stalks of wheat were cut at the top so as to leave behind, after fallen wheat ears had been collected by the gleaners, both modest pasture for the animals and much needed nourishment for the soil. The absence of a micro-serrated edge that would have facilitated the cutting of sheaves while preserving the ears of wheat, suggests that these sickles were used to cut not only ripe wheat but also other herbaceous species. See, for example, the miniature illustrating the Month of August in the Aratea manuscript ${ }^{53}$, the sculpture depicting the Month of June in Antelami's Cycle of the Months at the Baptistery of Parma (1210-1215 ca.), or the stained glass representation of the Labours of the Months, part of Chartres Cathedral's Royal Portal (1145-1155).

The billhook, being a "ferramentum ad runcandum aptum ${ }^{54}$, was useful in the pruning of trees and vines (Illustrations 8, 10 and 11). The 11 specimens recovered are two-edged $(25 \times 4 \mathrm{~cm})$, with a thick, flat, hooked blade, an additional rectangular blade located opposite the edge, half way along the spine of the tool, and a tang for the handle. Similar tools, dating from the same period, have been found in Montagliano in Sabina ${ }^{55}$ as well as in Segesta ${ }^{56}$. Strict iconographic parallels can be found in an Exultet roll made at Montecassino ${ }^{57}$ in the mid- $11^{\text {th }}$ century, and in a French calendar (Month of March) by Sano di Pietro.

Finally, the two axes $(18 \times 9 \mathrm{~cm})$ brought to light evoke the forest (Illustrations 8 and 12), the clearing of the "silva infructuosa". They have a trapezoid blade, an arched front edge and a long tubular eye where the handle is mounted. The short and compact head made these tools suitable for cutting resistant plant material such as wood and roots ${ }^{58}$. Suffice it to mention the famous miniature of the capital letter «|» showing a woodcutter at work in Citeaux's Moralia in Job ${ }^{59}$.

The analysis of this admittedly small sample of agricultural equipment, in which, as we have seen, the relationship between form and function predominates, can benefit from a largely techno-anthropological approach. To paraphrase Enrico Giannichedda (2014, p. 85), the artisan makes his appearance on the scene as a manufacturer able to improve the functionality of the artefacts vis-à-vis the prospective users, in this case, the peasants. The stage on which this story unfolds

53 Österreichische Nationalbibliothek, Wien, Österreich, Aratea, 387, f. 90v (ca. 830).

${ }^{54}$ Forcellini, 1940, s.v. Runca.

55 De Minicis \& Hubert, 1991, ill. 28/12, p. 523.

${ }^{56}$ Molinari, 1997, ill. 197/V.1, p. 175.

57 Biblioteca Apostolica Vaticana, Città del Vaticano, Exultet, Barb.Lat. 592.

58 "Instrumentum ferrum simile dolabrae, quo utuntur rustici terrae fodiendae, herbis evellendis, radicibus extirpandis» (Forcellini, 1940, s.v. Ascia). Gambaro, 1990, ill. XII/49, p. 396; Ermeti \& Sacco \& Vona, 2008, ill. 4/13, p. 169.

${ }^{59}$ The manuscript (12 $2^{\text {th }}$ century) is kept at Bibliothèque Municipale de Dijon, Dijon, France, 170. 
is the faber's workshop (unit H) discovered at Leopoli-Cencelle, where metal, mostly iron, was produced. A forge was unearthed, in which the initial phase of reduction and the processing of iron probably took place. The high technological level of production can be deduced both from the sheer number (over 6000) and diversity of the metal artefacts found (objects linked to construction, working tools, furnishings, personal care items, military equipment and tack for pack and draft animals), and from the presence of haematite from Elba. As Vasco La Salvia's metallographic analyses confirmed ${ }^{60}$, this mineral was used to supplement the iron deposits of the Tolfa basin, which were not rich enough to be used by themselves. The artefacts could then be finished or, if need be, repaired in a shop located around the corner (Illustration 13) in a group of terraced houses ${ }^{61}$. The recovery of rainwater collection tanks, of hearths and of work counters suggests that this was a simple, rudimentary workshop, possibly used also as a retail shop selling iron artefacts, especially farming tools as well as materials for furniture and for construction.

Iron -an element of relatively little intrinsic value- is thus enriched by virtue of the use value of the finished product fit for a specific purpose. Ultimately, it is precisely this usefulness, resulting from the investment of know-how and long working hours, that determines the worth of the final product ${ }^{62}$.

The processing of iron by specialised workers between the $13^{\text {th }}$ and $14^{\text {th }}$ centuries is part of a general shift involving the introduction and spread of metal workshops in rural towns, followed by the improvement and proliferation of metal workingtools ("ferri apti a lavorare»). This phenomenon represented a momentous change in the lives of the communities that depended on revenues from agriculture, and conferred high socio-economic standing on artisans, including the metalworkers of Cencelle. Thus, the blacksmiths Matheus Alexii and Guarnerius feature among the town's eminent citizens, members of the town meeting, and among those who in 1220 signed the deed of submission to Viterbo on behalf of the entire community of Cencelle. Leopoli's inhabitants could probably count on the smithy and the adjacent shop to meet any hardware-related need: from the shoeing of animals to the production of nails, hinges and scissors, and from the maintenance and repair of farming tools to their production. Chapter XLV of the Statute of Civitavecchia $\left(15^{\text {th }}\right.$ century copy) - "De la pena de li ferrari che non ferrano ${ }^{63}$ - corroborates this reading. The agricultural character of the community of Civitaveccha, similar in this respect to that of Cencelle, is highlighted by the fact that the duty to shoe animals was extended to draft animals other than horses, and by the rule that each

${ }^{60}$ La Salvia, 2000b.

${ }^{61}$ Martorelli, 2012.

62 Belli, 2002.

63 "Anche che ciascuno fabro de vomeri e d'altri ferri apti a lavorare sia tenuto a la pena de $X$ soldi exercitare l'arte sua» (Toti, 1992). 
blacksmith should "exercitare l'arte sua» by making "vomeri e d'altri ferri apti a lavorare»; clearly, farming tools. The work consisted of both producing new tools and - to a larger extent - repairing tools that had been deguastati o rupti ${ }^{64}$.

Having discussed the loci of production, thanks to the archaeological contexts of recovery we may now consider the loci of storage of farming tools. Thus, the fortuitous finding of a complete set of tools ${ }^{65}$ ( 2 hoes, 1 sickle, 3 billhooks and 2 axes), coupled with other archaeological indicators, allowed us to identify a storeroom (unit B, sector III) that is likely to have included a granary (for cereals and legumes) either at the top floor, or in a sort of wooden, clay-covered gallery (Illustration 14B). This granary was adjacent to, but separate from the house to which it belonged. The morphometric analysis of Triticum aestivum L. caryopses showed the grains to be relatively homogeneous in size. This, as well as the absence of weeds, supports the hypothesis that this was where seeds were stored. The unit, which is rather small $(4.40 \times 2.80 \mathrm{~m})$, is located at the centre of the sector. Within its northern sidewall, a vertical, semi-circular duct (45 cm in diameter) is embedded, which opens onto the ground with an arch, ensuring the ventilation of the granary. Furthermore, one can almost make out, under an animal shed, a mixed storage space for farming tools and domestic utensils in an enclosed, open air courtyard (Illustrations 14-F and 15) allowing pedestrian through-traffic (unit F, sector III) ${ }^{66}$. This storage space was at the exclusive disposal of the inhabitants of the adjacent dwelling (unit $E$, Illustration 14-E).

A little further to the west of the above-mentioned courtyard, a large rectangular building is subdivided into two communicating units (Illustrations $14-P / R$ and 16 ): a dwelling $(P)$ and an annex (R). The latter is a storeroom for tools, originally a barn, where one can still see the base that must have held a wooden feeding-trough. Between the $14^{\text {th }}$ and $15^{\text {th }}$ centuries, the southern area of the complex suffered another fire. Traces of this disastrous event are still visible in the large reserve of grain and in the ceramic tableware sealed by the burned wooden beams.

The three storage facilities (storeroom-granary, storeroom-barn and storeroomcourtyard) are thus located in the eastern quarter (sector III), in close proximity to the town's main gate, along the "via carraia" and its branches, and seem to have been intended for family use in the context of dwellings and their annexed storerooms.

${ }^{64}$ Equipment available in 1388 to Tirante di Pietro di Rinaldo from Tibur: «3 çappas deguastatas, 2 zappitellas, 2 acceptas, unum zapponem, unam asciam deguastatam et certam quantitatem de ferro rupto, 4 ronche, 1 zappitella» (De Angelis, 1981).

65 Tools belonging to a farmer from «castrum Capralice» (1340): «unum çapponem, unam ronculam, unam vangarellam, unam palam de ferro, unam çapparellam» (Archivio di Stato di Viterbo, Viterbo, Italia, Not. Capranica, 313, f. 28r-v).

${ }^{66}$ Bougard \& Cirelli, 2012. 
Remains of wheat were also found in the south-eastern residential quarter (sector II), especially in the latest phases of infill of the large cistern located in the square onto which most of the houses opened, and which separates this lot (sector II) from the adjacent one (sector I). These traces attest to the existence of facilities for the milling of cereals within the walls, possibly suggesting that out-of-town mills had suffered irreparable damage as a result of the 1349 earthquake.

As demonstrated by numerous archaeological case studies, the late-medieval practice of storing farming tools in domestic settings, often in separate spaces serving as barns, was almost universal in Italy. In Rocca San Silvestro ${ }^{67}$, for example, a single unit (area 5000) is subdivided into a dwelling and a separate subunit used to store agricultural equipment and shelter draft animals. Other examples are Zignago ${ }^{68}$, where the houses on the slope have large living quarters uphill and service areas (storerooms, workshops and barns) downhill; or Geridu ${ }^{69}$, where, in structures 3000/1 and 3000/2, living areas on the one hand, and storage areas for food and farming tools on the other, intermingle.

The storerooms offer further insight into the peasants' routine activities and organisation of work spaces. It is up to us to interpret how these spaces were perceived in the monotonous repetition of the life of a peasant, interrupted only by moments of socialisation such as attending mass at St. Peter's church, meeting people at the local inn (taverna), going to market, to the mill or to the faber's workshop (in light of the recovery of a collection of one-litre jugs and of a number of rolling dice, the inn was probably one of the units along "via carraia»; the market and the mill have been identified outside the walls, along the Mignone river and the Melledra stream, respectively, both in the vicinity of the town).

I will conclude with an image evoked by the documents, that of the "populus Centumcellensis simul ad sonum canpane coadunatus» ${ }^{70}$ ("the people of Centumcellae as though summoned by the sound of church bells»), a «musical call $\rangle^{71}$ that had become an organisational instrument of the social and religious life of the community ${ }^{72}$; a call that set the simple pace of the fields every day.

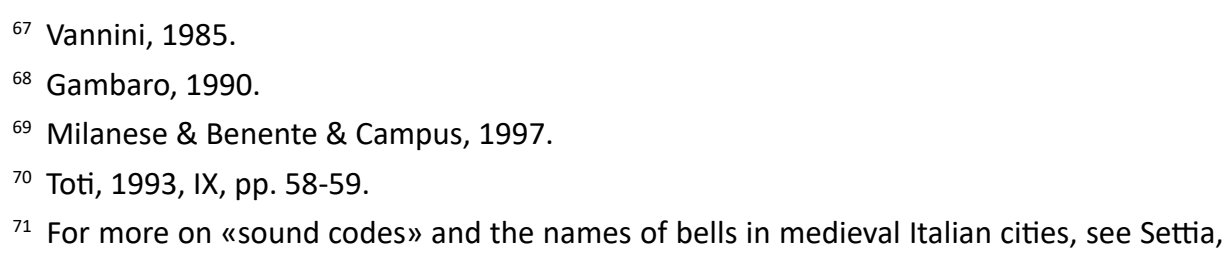
2007.

72 Le Goff, 1987, pp. 12-17; Cherubini, 1987. 


\section{FIGURES}
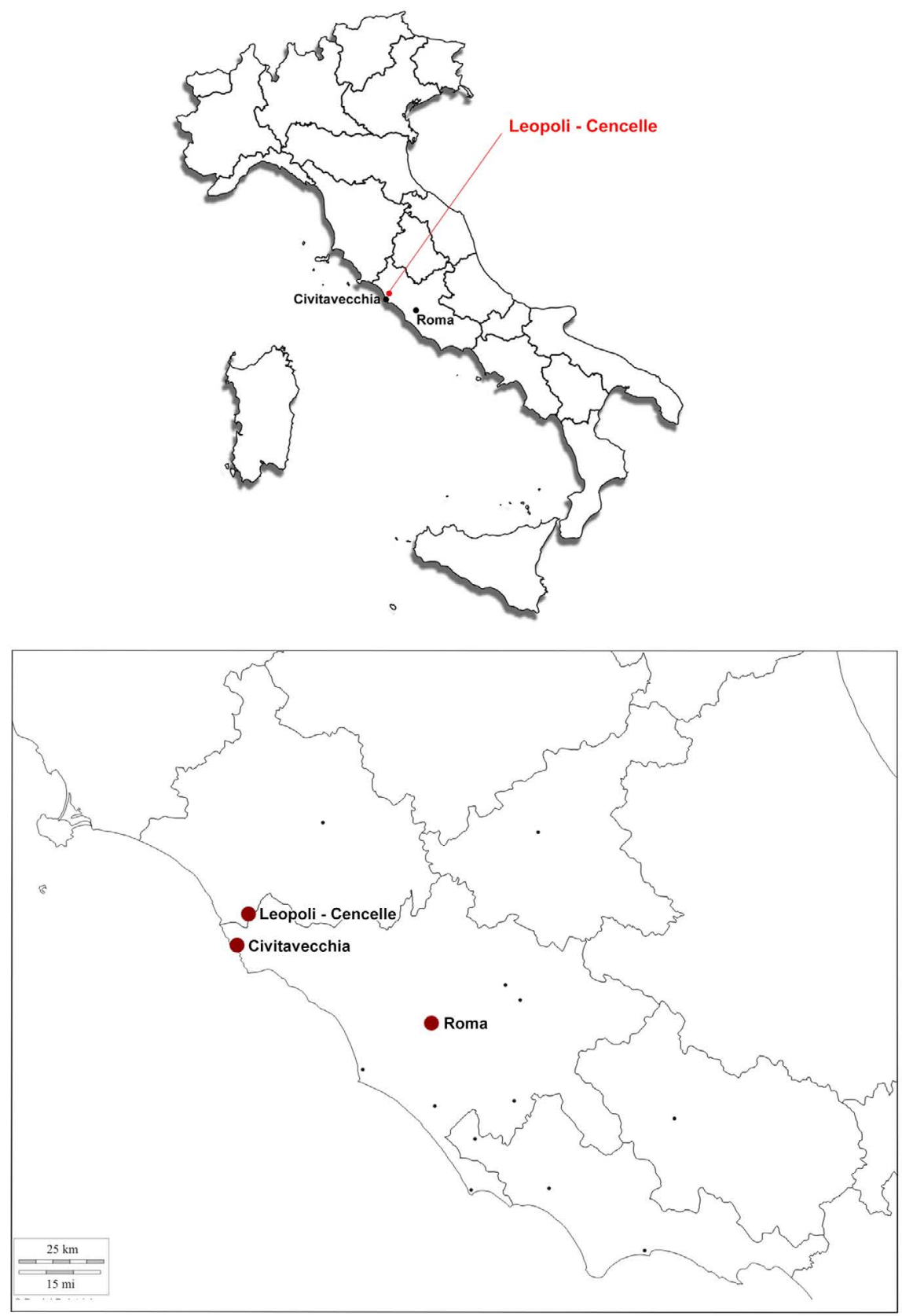

Illustration 1. Location of Leopoli-Cencelle. 


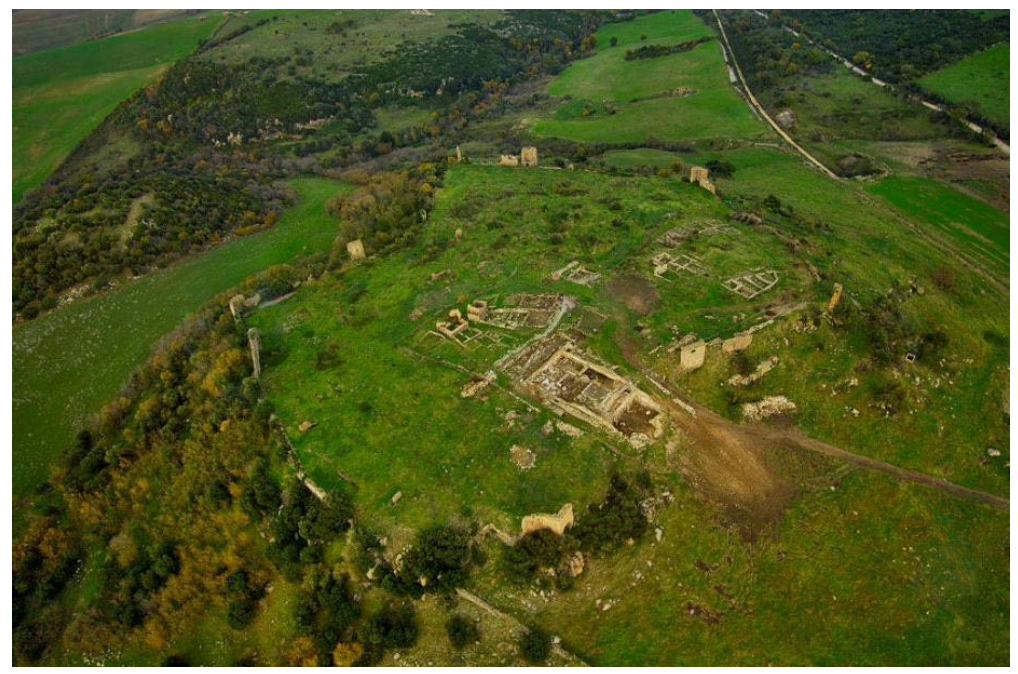

Illustration 2. The civitas of Leopoli-Cencelle viewed from south-west. (Source: Archivio Fotografico Cencelle, Sapienza University of Rome).

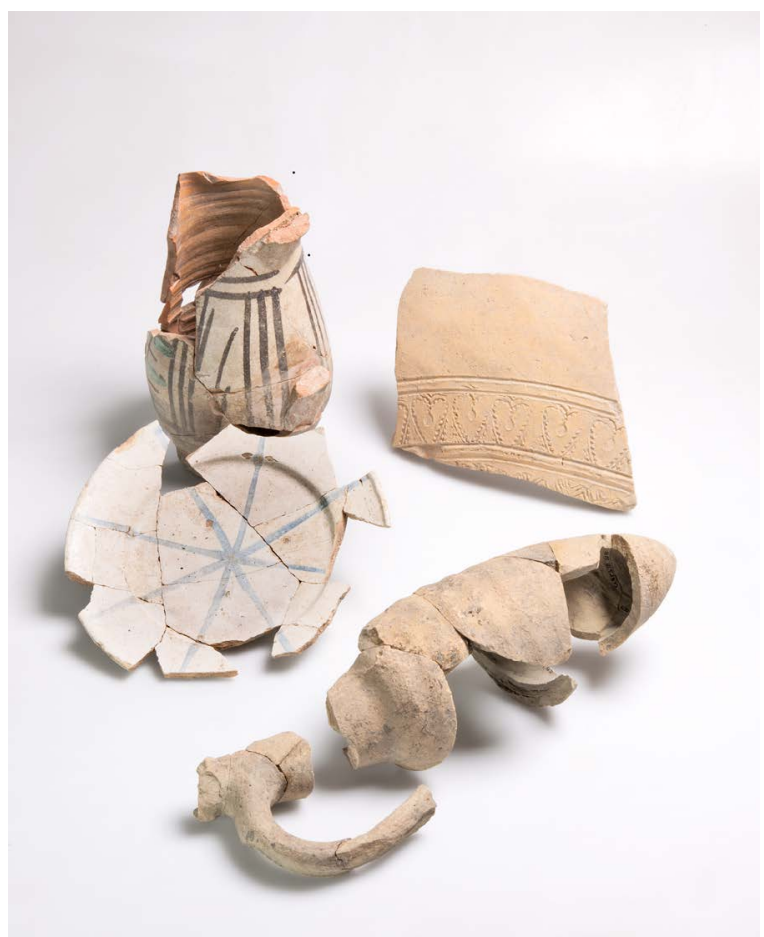

Illustration 3. Cencelle imported ceramic artefacts. (Photos author: Mauro Benedetti, Soprintendenza per i Beni Archeologici dell'Etruria Meridionale). 


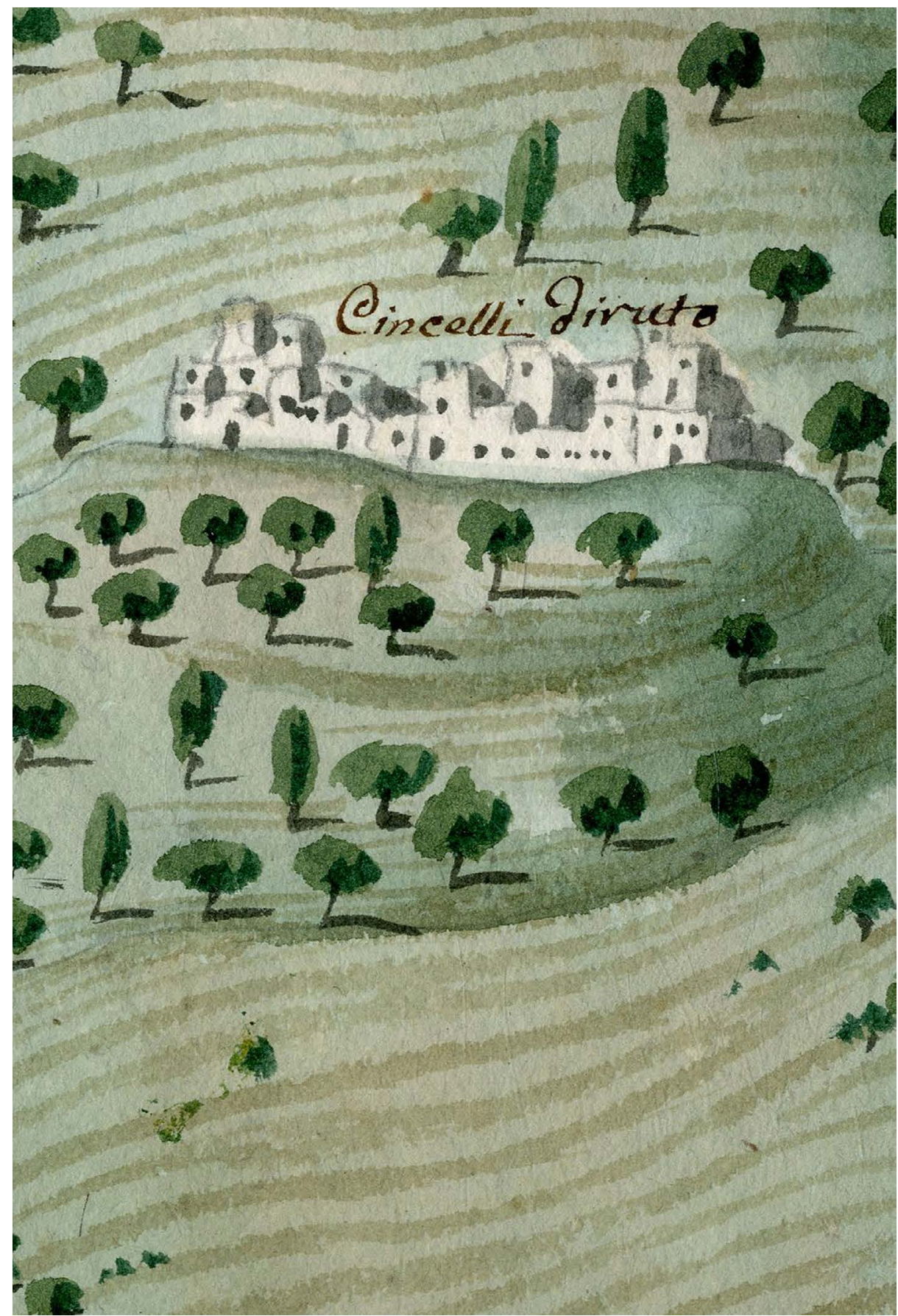

Illustration 4. Tenuta di Cincelli in 1696 Catasto delle Tenute di Allumiere of Giovanni Battista Cingolani (Roma Archivio di Stato, Catasto Cingolani, Disegni e Piante, cart. 122, F. 211, Tav. 16). 


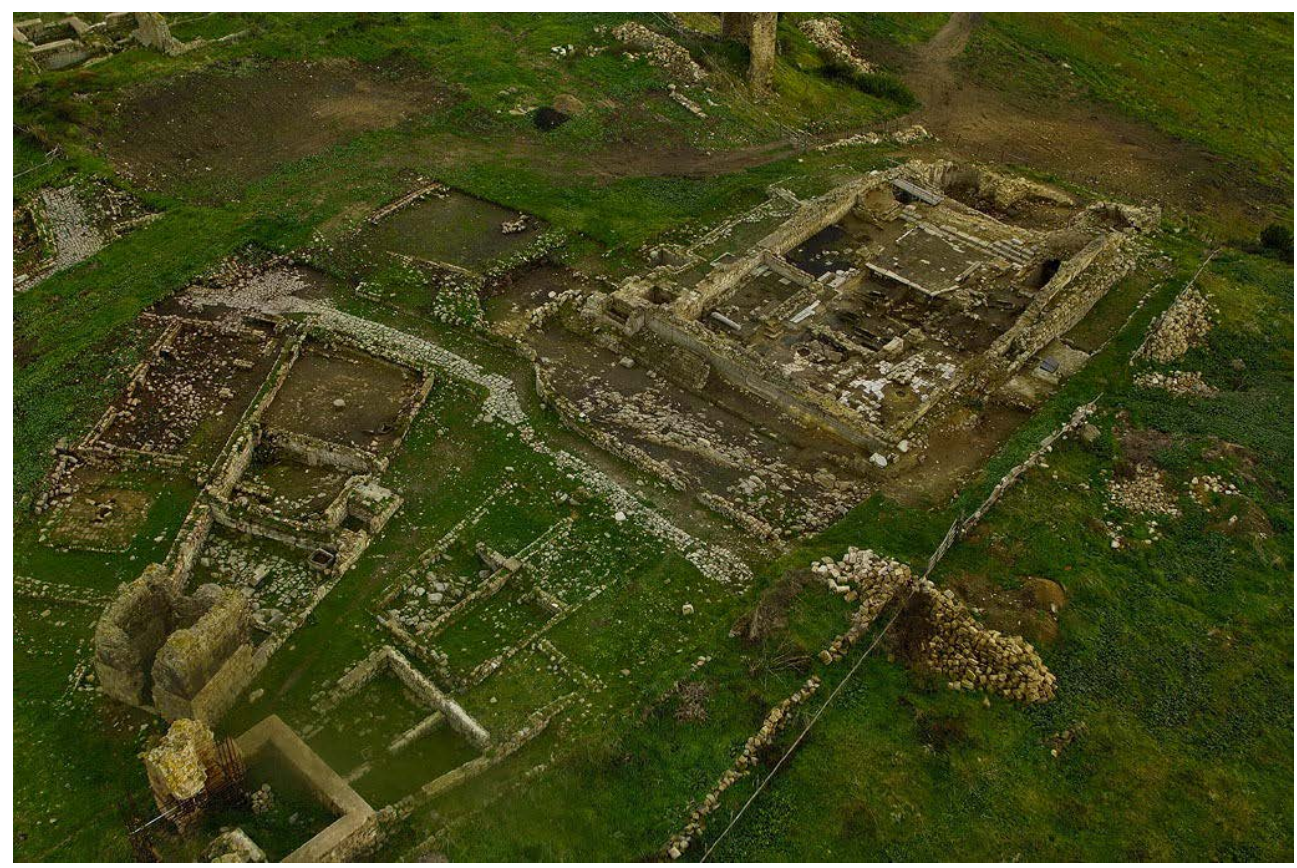

Illustration 5. St. Peter's Basilica and the civic centre viewed from north-west. (Source: Archivio Fotografico Cencelle, Sapienza University of Rome). 


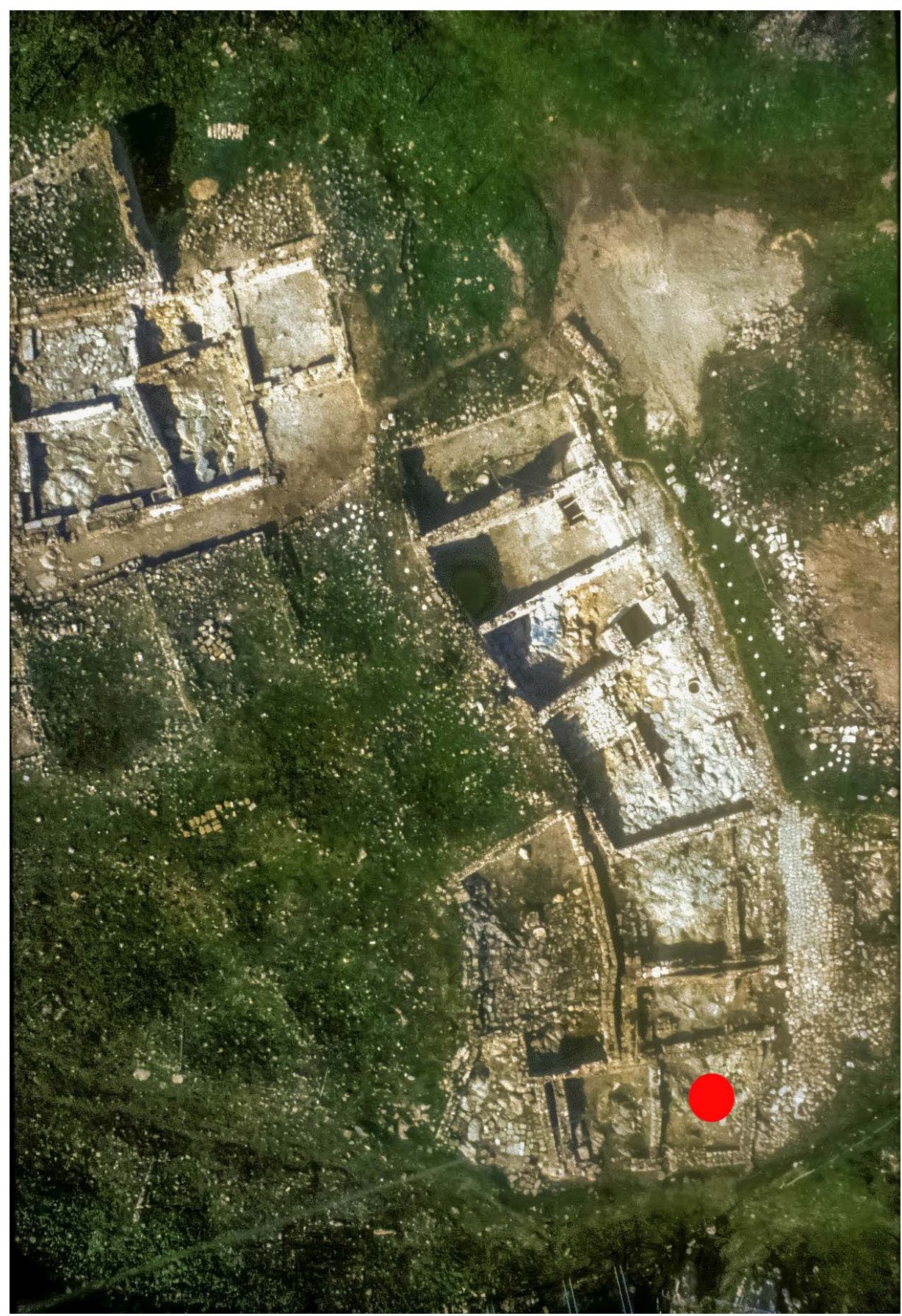

Illustration 6. Artisans' Quarter (sector III): the dot indicates faber's workshop, Unit H. (Source: Archivio Fotografico Cencelle, Sapienza University of Rome). 


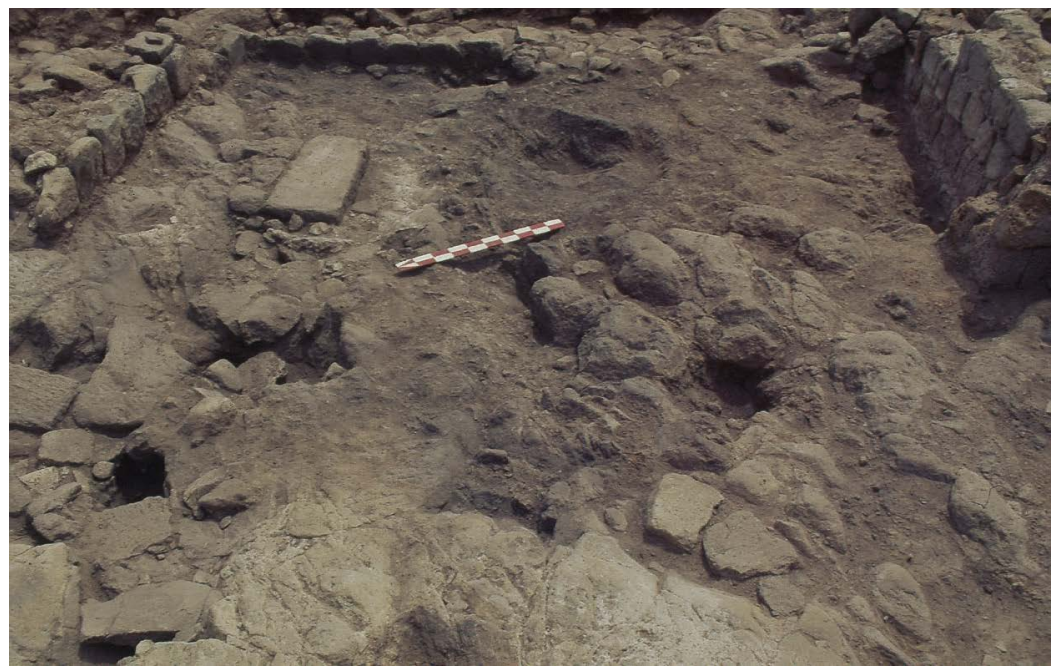

Illustration 7. The smithy workshop (Unit H) viewed from north-west. (Source: Archivio Fotografico Cencelle, Sapienza University of Rome).

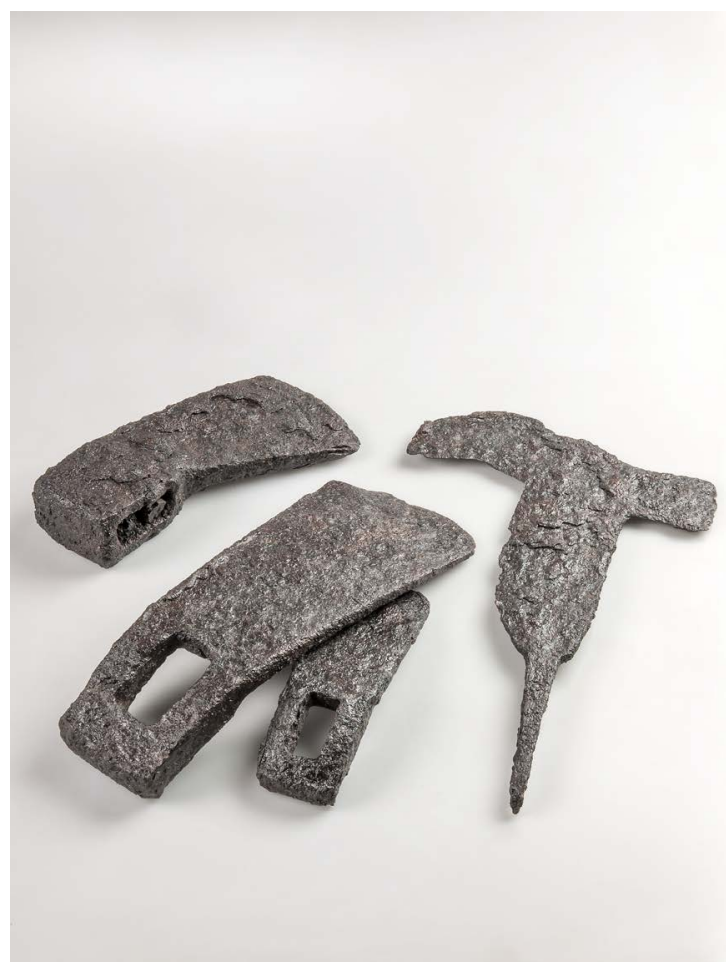

Illustration 8. Ax, hoes and billhook from Leopoli-Cencelle. (Photos author: Mauro Benedetti, Soprintendenza per i Beni Archeologici dell'Etruria Meridionale). 


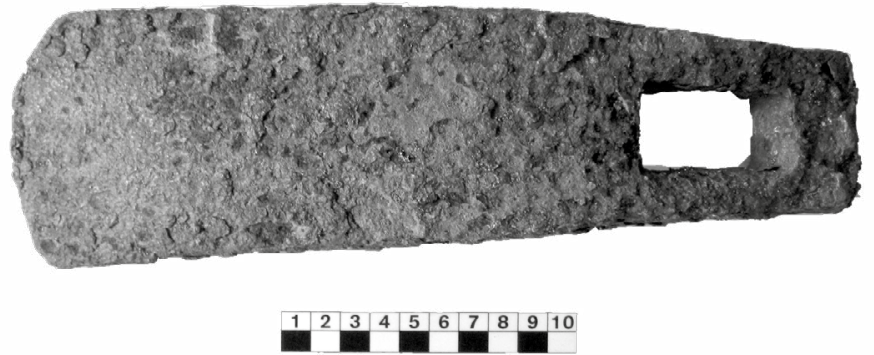

Illustration 9. Hoe from Leopoli-Cencelle. (Source: Archivio Fotografico Cencelle, Sapienza University of Rome).

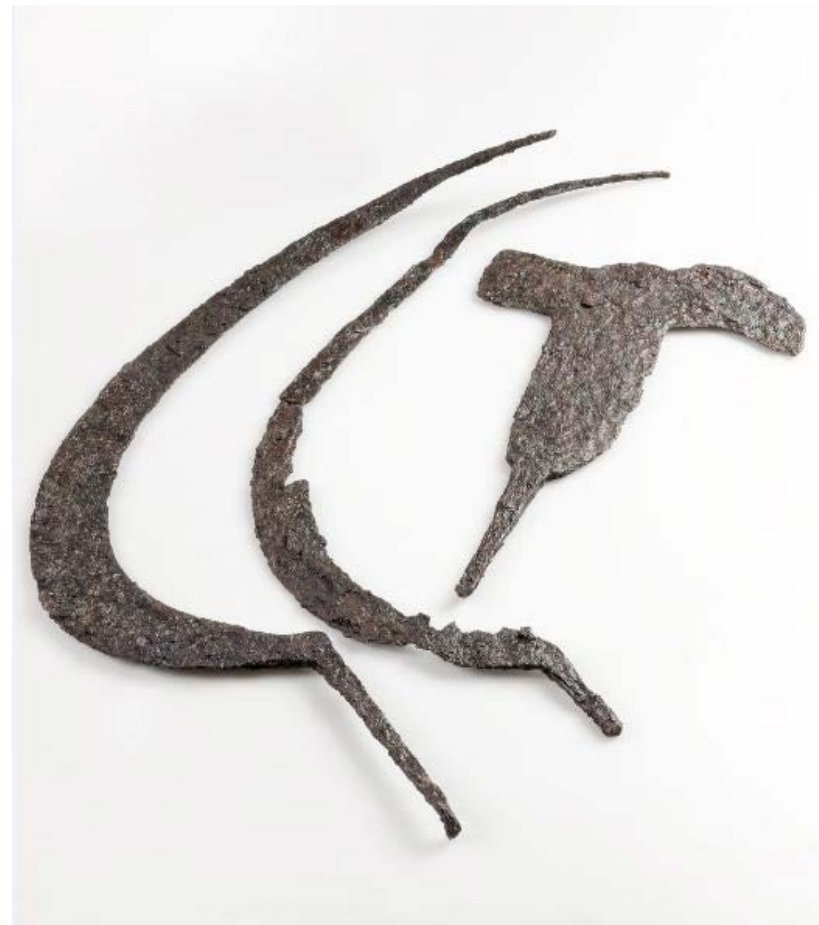

Illustration 10. Sickles and billhook from Leopoli-Cencelle. (Photos author: Mauro Benedetti, Soprintendenza per i Beni Archeologici dell'Etruria Meridionale). 


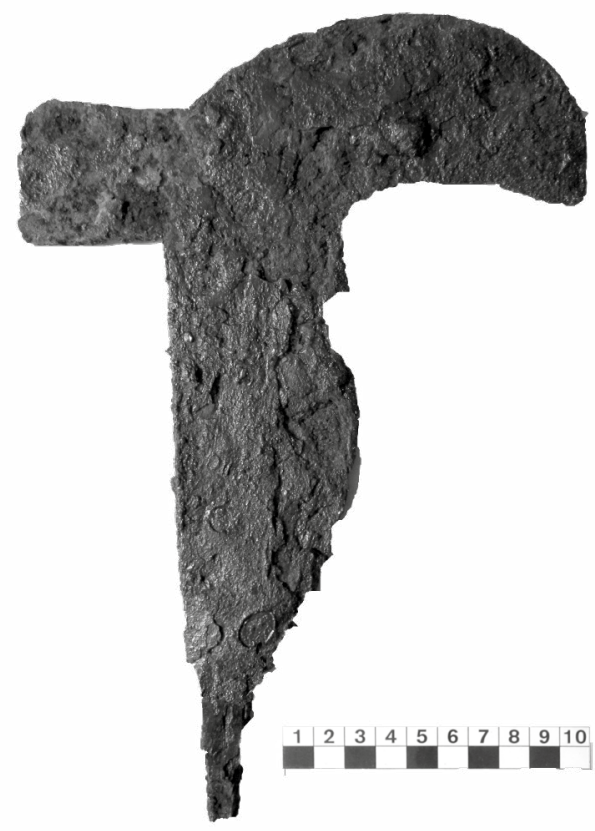

Illustration 11. Billhook from Leopoli-Cencelle. (Source: Archivio Fotografico Cencelle, Sapienza University of Rome).

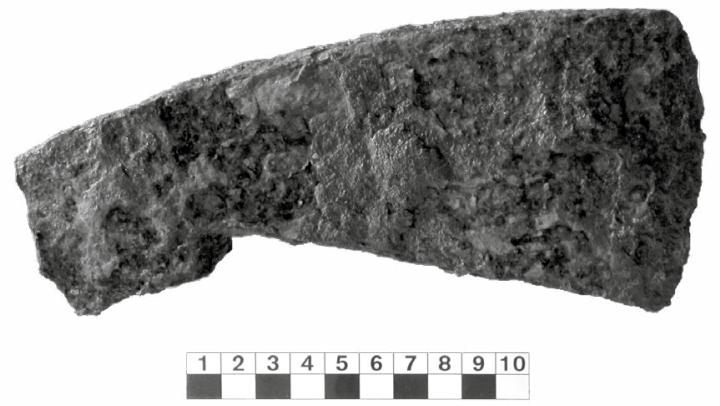

Illustration 12. Axe from Leopoli-Cencelle. (Source: Archivio Fotografico Cencelle, Sapienza University of Rome). 


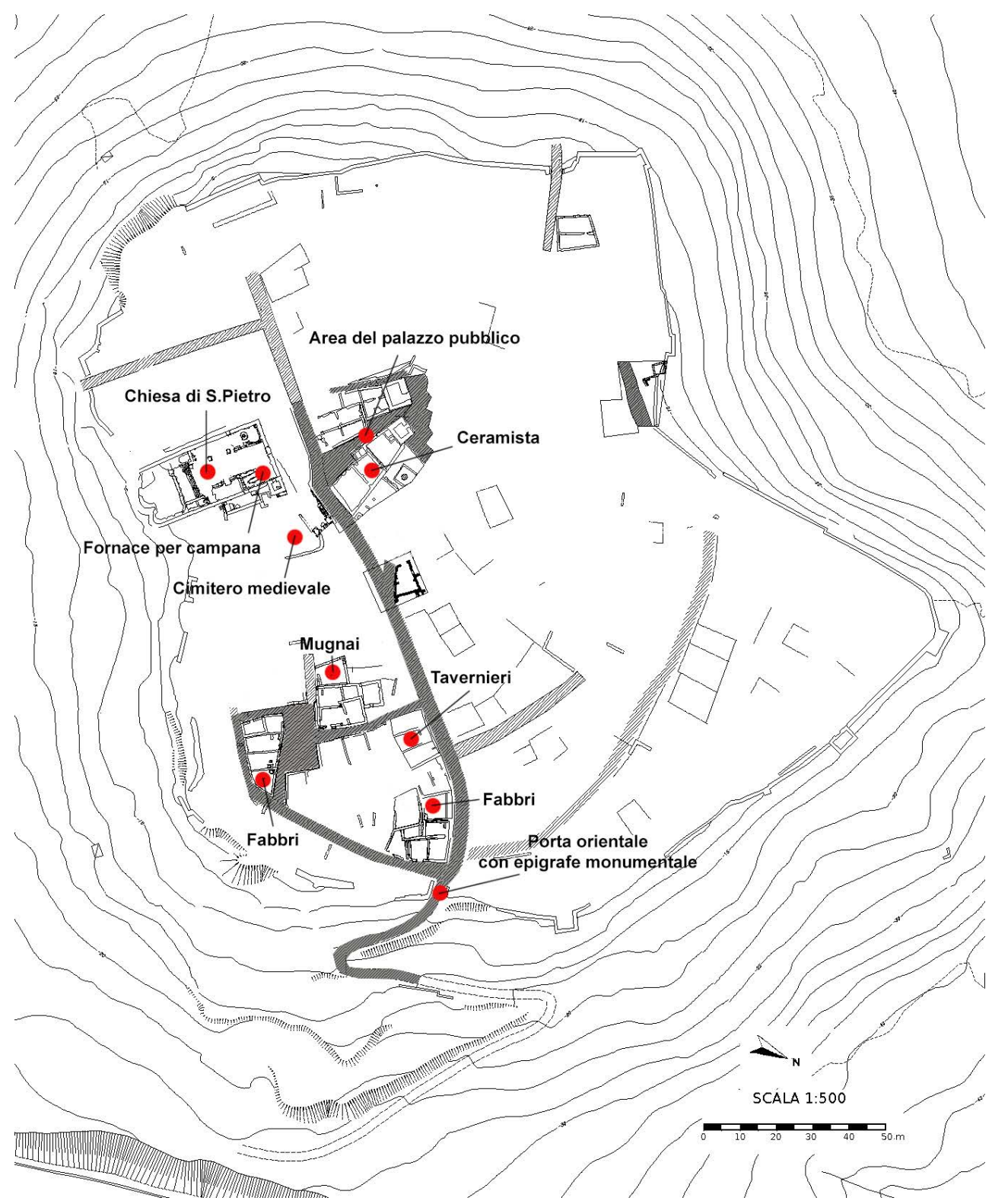

Illustration 13. Side plan of Leopoli-Cencelle with the artisanal activities highlighted. (Source: Archivio Fotografico Cencelle, Sapienza University of Rome). 

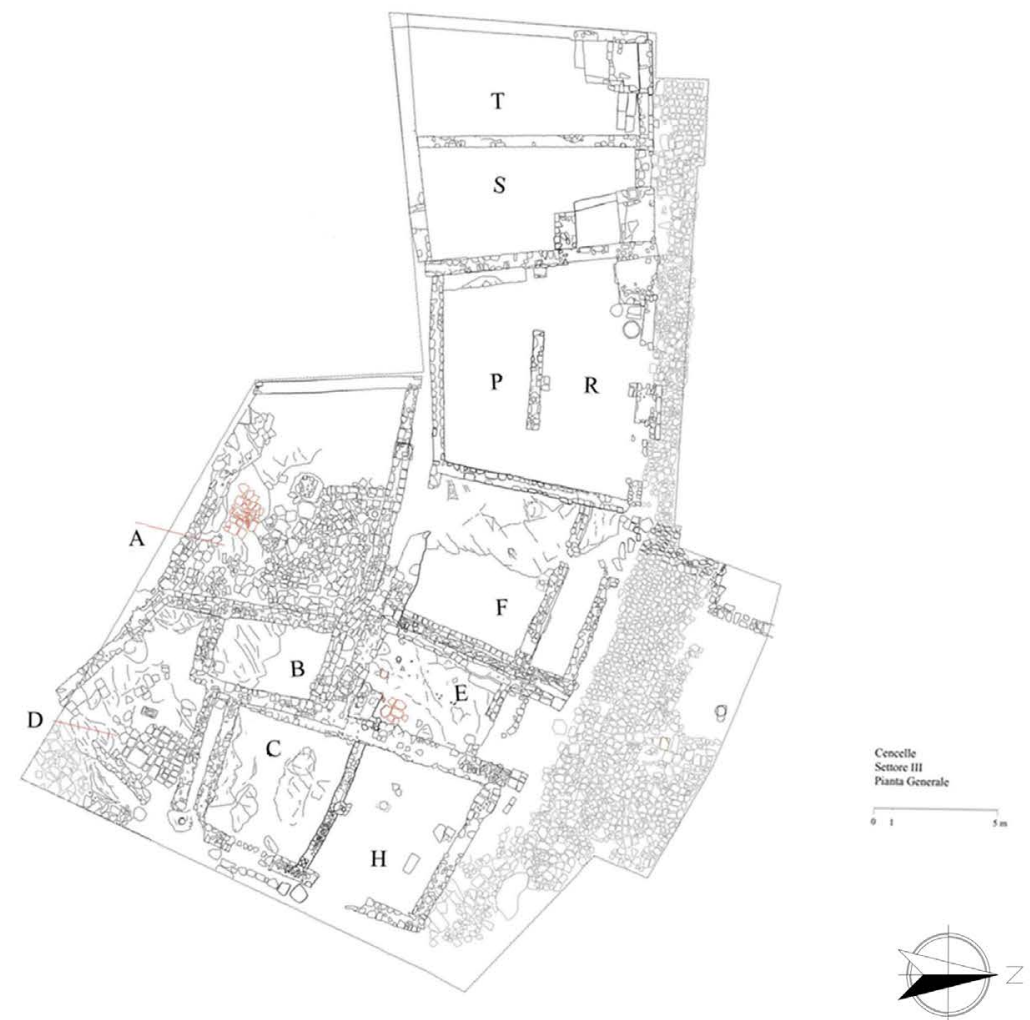

Illustration 14. Side plan of sector III. (Source: Archivio Fotografico Cencelle, Sapienza University of Rome). 


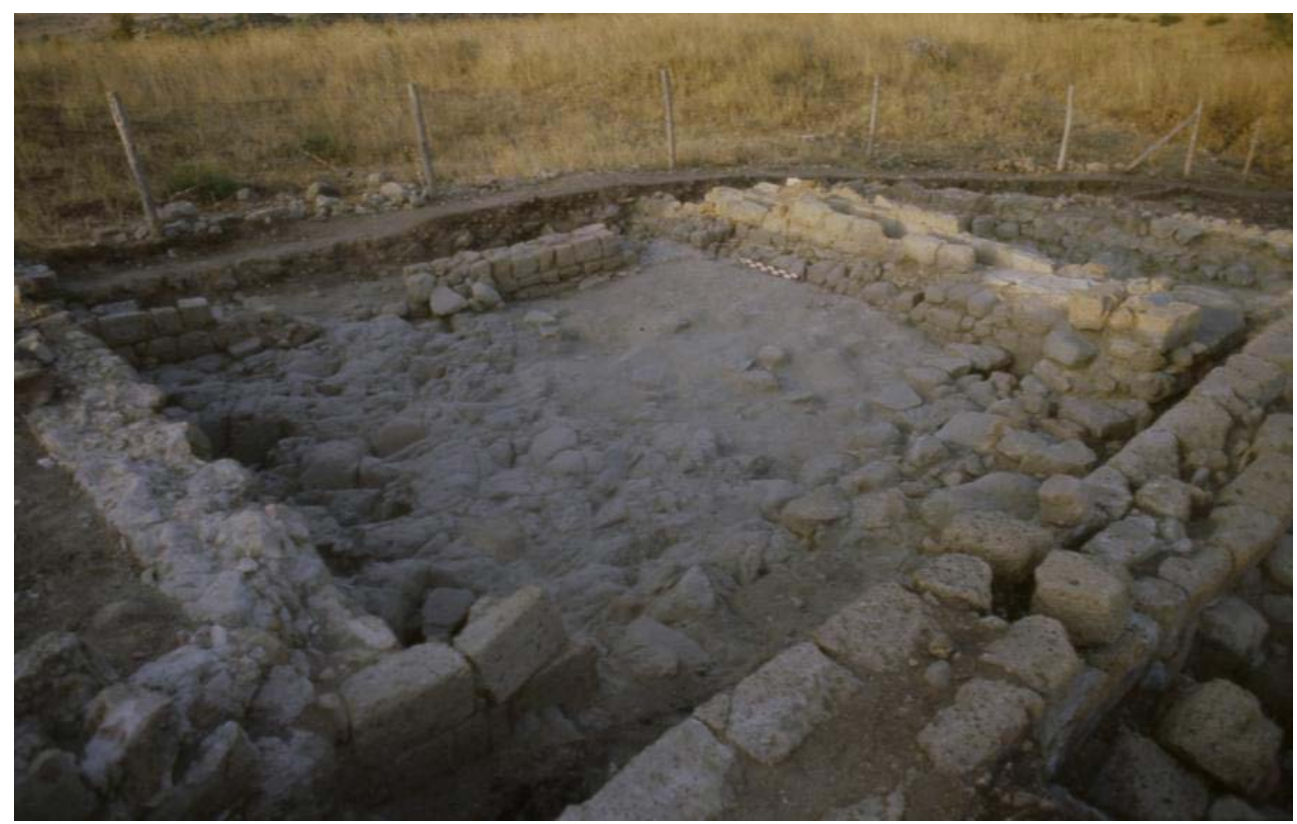

Illustration 15. Leopoli-Cencelle: open air courtyard (Unit F) viewed from north-west. (Source: Archivio Fotografico Cencelle, Sapienza University of Rome).

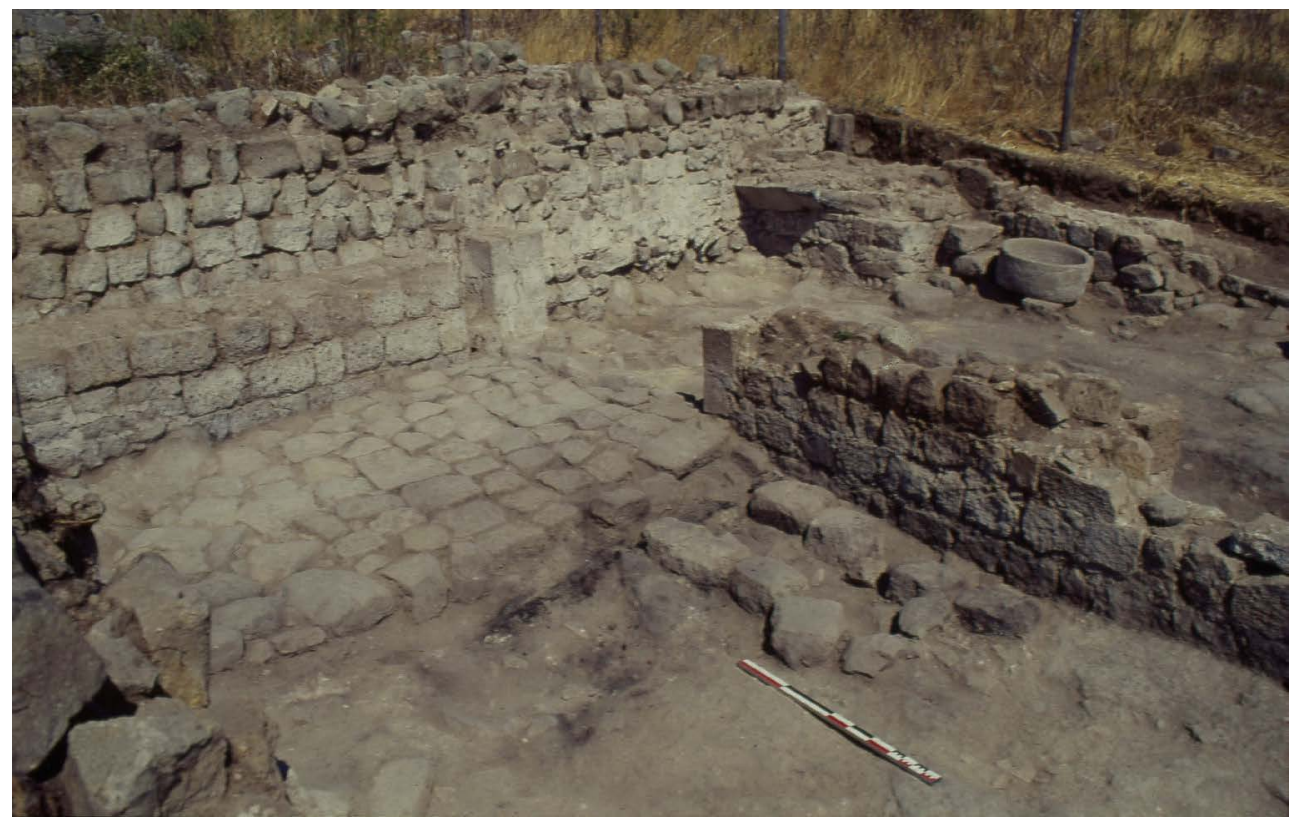

Illustration 16. Units P-R viewed from south-east. (Source: Archivio Fotografico Cencelle, Sapienza University of Rome). 


\section{BIBLIOGRAPHICAL REFERENCES}

Abulafia, D. S. H. (2007). Ripensando il ruolo di Corneto nell'ambito dei commerci tra Genova e la Toscana nel Duecento. In A. Cortonesi, A. Esposito, L. Ermini Pani (Eds.), Corneto medievale: territorio, società, economia, istituzioni religiose. Atti del convegno (Tarquinia, 24-25 novembre 2007) (pp. 69-84). Tarquinia: Società Tarquiniense di Arte e Storia.

Ait, I. (2010). I Margani e le miniere di allume di Tolfa: dinamiche familiari e interessi mercantili fra XIV e XVI secolo. Archivio Storico Italiano, 168, 231-262.

Amici, S. (1989). Ripafratta (Pisa). 3. I reperti metallici e non metallici delle campagne di scavo 1983-1984. Archeologia Medievale, 16, 460-479.

Annoscia, G. M. (2012). La ceramica. In F. R. Stasolla (Ed.), Leopoli-Cencelle: il quartiere sud-orientale (pp. 245-252). Spoleto: Centro Italiano di Studi sull'Alto Medioevo.

Barceló, M. (1988). Arqueología Medieval. En las afueras del "medievalismo». Barcelona: Crítica.

Barceló, M. (1995). Crear, disciplinar y dirigir el desorden. La renta feudal y el control del proceso de trabajo campesino: una propuesta sobre su articulación. Taller d'Història, 6(2), 61-72.

Baruzzi, M. (1987). I reperti in ferro dello scavo di Villa Clelia (Imola). Note sull'attrezzatura agricola nell'Altomedioevo. In R. Francovich (Ed.), Archeologia e storia del Medioevo italiano (pp. 150-170). Roma: La Nuova Italia Scientifica.

Belli, M. (2002). I reperti metallici provenienti dallo scavo di Castel di Pietra: studio preliminare dei contesti e presentazione della tipologia morfologica. Archeologia Medievale, 29, 142-162.

Bougard, F. et al., (1996). Settore III. In Leopoli-Cencelle. Una città di fondazione papale. Catalogo della Mostra (pp. 64-68). Roma: Fratelli Palombi Editori.

Bougard, F., Cirelli, E. (2012). Settore III. In F. R. Stasolla (Ed.), Leopoli-Cencelle: il quartiere sud-orientale (pp. 181-196). Spoleto: Centro Italiano di Studi sull'Alto Medioevo. 
Brufal Sucarrat, J. (2013). El món rural i urbà en la Lleida islàmica (s. XI-XII). Lleida i l'est del districte: Castelldans i el pla del Mascançà. Lleida: Pagès editors.

Calisse, C. (1936). Storia di Civitavecchia. Firenze: Barbera.

Casocavallo, B., Camardo, D. (2005). Analisi dei rinvenimenti di ceramiche ispanomoresche nel centro urbano di Tarquinia (VT). In E. De Minicis, A. M. Giuntella (Eds.), Le ceramiche di Roma e del Lazio in età medievale e moderna. Atti del V Convegno di Studi (Chieti 2002) (pp. 312-320). Roma: Edizioni Kappa.

Castiñeiras González, M. A. (1991). Mesi. In Enciclopedia dell'Arte Medievale (pp. 325-335). Roma: Istituto dell'Enciclopedia Italiana.

Cataldi, M., Casocavallo, B. (2007). Archeologia urbana a Tarquinia: trenta anni di tutela nel centro storico. In A. Cortonesi, A. Esposito, L. Ermini Pani, Corneto medievale: territorio, società, economia, istituzioni religiose. Atti del convegno (Tarquinia, 24-25 novembre 2007) (pp. 169-206). Tarquinia: Società Tarquiniense di Arte e Storia.

Cherubini, G. (1987). II contadino e il lavoro dei campi. In J. Le Goff (Ed.), L'uomo medievale (pp. 127-153). Bari: Editori Laterza.

Cirelli, E. (2002). Produzione locale e dinamiche commerciali a Leopoli-Cencelle. In E. De Minicis, G. Maetzke (Eds.), Le ceramiche di Roma e del Lazio in età medievale e moderna. Atti del IV Convegno di Studi (Viterbo 1998) (pp. 266293). Roma: Edizioni Kappa.

Comet, G. (1992). Le Paysan et son outil. Essai d'histoire technique des céréales (France, VIII $-X V^{e}$ siècle). Roma: École Française de Rome.

Cortonesi, A. (1988a). Terre e signori nel Lazio medioevale. Napoli: Liguori.

Cortonesi, A. (1988b). Il lavoro del contadino: uomini, tecniche, colture nella Tuscia tardo medioevale. Bologna: CLUEB.

Cortonesi, A., Esposito, A., Ermini Pani, L. (2007). Corneto medievale: territorio, società, economia, istituzioni religiose. Atti del convegno (Tarquinia, 24-25 novembre 2007). Tarquinia: Società Tarquiniense di Arte e Storia.

De Angelis, L. (1981). Tecniche di coltura agraria e attrezzi agricoli alla fine del Medioevo. In Civiltà ed economia agricola in Toscana nei secoli XIII-XV: problemi 
della vita delle campagne nel tardo medioevo. Ottavo Convegno internazionale (Pistoia, 21-24 aprile 1977) (pp. 203-220). Pistoia: Centro Italiano Studi di Storia e d'Arte.

Démians d'Archimbaud, G. (1980). Les fouilles de Rougiers. Contribution à l'archéologie de l'habitat rural médiéval en pays méditerranéen. Paris: CNRS.

De Minicis, E., Hubert, É. (1991). Indagine archeologica in Sabina: Montagliano, da Casale a «castrum» (secc. IX-XV). Archeologia Medievale, 18, 491-556.

De Minicis, E. (2012). Settore II. Lo scavo archeologico. In F. R. Stasolla (Ed.), LeopoliCencelle: il quartiere sud-orientale (pp. 143-156). Spoleto: Centro Italiano di Studi sull'Alto Medioevo.

Ermeti, A.L., Sacco, D., Vona, S. (2008). Il castello di Monte Copiolo nel Montefeltro (Marche). Le prime sei campagne di scavo (2002-2007), una sintesi. Archeologia Medievale, 35, 151-173.

Ermini Pani, L. (2012). Il progetto Leopoli-Cencelle: una città di fondazione papale. In F. R. Stasolla (Ed.), Leopoli-Cencelle: il quartiere sud-orientale (pp. 1-15). Spoleto: Centro Italiano di Studi sull'Alto Medioevo.

Ermini Pani, L., Somma, M.C., Stasolla, F.R. (2014), Forma e vita di una città medievale (Form and life of a medieval city): Leopoli-Cencelle. Spoleto: Centro Italiano di Studi sull'Alto Medioevo.

Forcellini, E. (1940). Lexicon Totius Latinitatis. Padova: Tipografia del Seminario.

Fumi, L. (1884). Codice diplomatico della città di Orvieto. Documenti e regesti dal secolo XI al XV. Firenze: G.P. Vieusseux.

Gambaro, L. (1990). Scavo nell'area est del villaggio abbandonato di Monte Zignago: Zignago 4. Catalogo dei materiali metallici. Archeologia Medievale, 17, 385-406.

Giannichedda, E. (2006). Uomini e cose. Appunti di archeologia. Bari: Edipuglia.

Giannichedda, E. (2014). Chi ha paura dei manufatti? Gli archeologi hanno paura dei manufatti? Archeologia Medievale, 41, 79-93.

Guidotti, A. (1981). Agricoltura e vita agricola nell'arte toscana del Tre e Quattrocento (di alcune miniature fiorentine e senesi del XV secolo). In Civiltà ed economia 
agricola in Toscana nei secoli XIII-XV: problemi della vita delle campagne nel tardo medioevo. Ottavo Convegno internazionale (Pistoia, 21-24 aprile 1977) (pp. 53-82). Pistoia: Centro Italiano Studi di Storia e d'Arte.

Jamme, A. (2005). Conscience et gestion de la crise dans le patrimoine de SaintPierre. Systèmes d'explotations, offices et pouvoirs à Cencelle (XIII $-\mathrm{XV}^{\mathrm{e}}$ siècle). Mélanges de l'École Française de Rome - Moyen Âge, 117(1), 353-406.

Kirchner, H. (2010). Por una arqueología agraria. Perspectivas de investigación sobre espacios de cultivo en las sociedades medievales hispánicas. Oxford: British Archaeological Reports.

La Salvia, V. (2000a). Produzione e lavorazione del ferro presso il sito medievale di Leopoli-Cencelle. Note per la storia mineraria dell'Etruria meridionale prima della scoperta dell'allume. In F. Fedeli Bernardini (Ed.), Metalli, Miniere e Risorse Ambientali: il territorio dei Monti della Tolfa tra medioevo ed età contemporanea (pp. 83-90). Roma: Assessorato alla cultura e alle politiche giovanili.

La Salvia, V. (2000b). Archeometallurgia. In R. Francovich, D. Manacorda (Eds.), Dizionario di archeologia (pp. 18-24). Roma-Bari: Laterza.

La Salvia, V. (2005). Appendice. In F. Zagari (Ed.), Il metallo nel Medioevo. Tecniche, strutture, manufatti, pp. 92-94. Roma: Fratelli Palombi Editori.

Le Goff, J. (1987). Tempo della Chiesa e tempo del mercante e altri saggi sul lavoro e la cultura nel Medioevo. Torino: Einaudi.

Le Liber Pontificalis I-II (Abbé Duchesne ed.). Paris: E. de Boccard, 1955-1957.

Maetzke, G. (1986). Fonte archeologica e processo socioculturale. In G. Donato, W. Hensel, S. Tabaczynski (Eds.), Teoria e pratica della ricerca archeologica. I. Premesse metodologiche (pp. 261-321). Torino: Il Quadrante.

Malalana Ureña, A., Morín de Pablos, J., Barroso Cabrera, R. (2013). Acerca de la funcionalidad de los denominados «silos-basureros»: una propuesta metodológica para el estudio de la agricultura andalusí en época califal y taifa. Archeologia Medievale, 40, 337-352.

Mane, P. (1991). Agricoltura. In Enciclopedia dell'Arte Medievale (pp. 239-249). Roma: Istituto dell'Enciclopedia Italiana. 
Mane, P. (2006). Le travail à la campagne au Moyen Âge: étude iconographique. Paris: Picard.

Mannoni, T., Giannichedda, E. (2003). Archeologia della produzione. Torino: Piccola Biblioteca Einaudi.

Martorelli, R. et alii (1996). I metalli. In Leopoli-Cencelle. Una città di fondazione papale, II (pp. 77-81). Roma: Fratelli Palombi Editori.

Martorelli, R. (2012). Settore I. In F. R. Stasolla (Ed.), Leopoli-Cencelle: il quartiere sud-orientale (pp. 123-142). Spoleto: Centro Italiano di Studi sull'Alto Medioevo.

Milanese, M., Benente, F., Campus, F. (1997). II progetto Geridu. Indagini archeologiche in un villaggio abbandonato della Sardegna. In S. Gelichi (Ed.), Atti del I Congresso Nazionale di Archeologia Medievale (Pisa, 29-31 maggio 1997) (pp. 120-128). Firenze: Edizioni All'Insegna del Giglio.

Minniti, C. (2012). Lo sfruttamento delle risorse. I resti archeozoologici. In F. R. Stasolla (Ed.), Leopoli-Cencelle: il quartiere sud-orientale (pp. 310-327). Spoleto: Centro Italiano di Studi sull'Alto Medioevo.

Molinari, A. (1997). Segesta II. II castello e la moschea (scavi 1985-1995). Palermo: Dario Flaccovio Editore.

Nardi Combescure, S. (2002). Paesaggi d'Etruria meridionale: l'entroterra di Civitavecchia dal II al XV secolo d.C. Firenze: All'Insegna del Giglio.

Palermo, L. (2007). II porto di Corneto tra Medioevo e Rinascimento. In A. Cortonesi, A. Esposito, L. Ermini Pani, Corneto medievale: territorio, società, economia, istituzioni religiose. Atti del convegno (Tarquinia, 24-25 novembre 2007) (pp. 85-98). Tarquinia: Società Tarquiniense di Arte e Storia.

Parenti, R. (1994). Attrezzi agricoli, utensili, armi, strumentario domestico e frammenti metallici. In S. Gelichi, N. Giordani (Eds.), Il tesoro nel pozzo. Pozzi deposito e tesaurizzazioni nell'antica Emilia (pp. 112-118). Modena: Panini.

Quirós Castillo, J. A. (2014). Oltre la frammentazione postprocessualista. Archeologia agraria nel nordovest della Spagna. Archeologia Medievale, 41, 23-37.

Quirós Castillo, J. A. (2014). Agrarian archaeology in Early Medieval Europe. Quaternary International, 346, 1-162. 
Settia, A. (2007). Codici sonori e nomi di campane nelle città medievali italiane. In S. Lusuardi Siena, E. Neri (Eds.), Del fondere campane: dall'archeologia alla produzione. Quadri regionali per I'Italia settentrionale. Atti del convegno (Milano 2006) (pp. 79-84). Firenze: All’Insegna del Giglio.

Savelli, M., Larocca, F. (2012). Lo sfruttamento delle risorse. I resti archeobotanici. In F. R. Stasolla (Ed.), Leopoli-Cencelle: il quartiere sud-orientale (pp. 297-310). Spoleto: Centro Italiano di Studi sull'Alto Medioevo.

Sogliani, F. (1995). Utensili, armi e ornamenti di età medievale da Montale e Gorzano. Modena: Franco Cosimo Panini.

Somma, M.C. (2014). La città comunale. II palazzo pubblico. I cantieri di Cencelle: maestranze, materiali e tecniche. In L. Ermini Pani, M. C. Somma, F. R. Stasolla (Eds.), Forma e vita di una città medievale (Form and life of a medieval city): Leopoli-Cencelle (pp. 25-27, 53-55, 63-65). Spoleto: Centro Italiano di Studi sull'Alto Medioevo.

Stasolla, F.R., Di Nezza, M., Doronzo, G. (2011). Materiali, tecniche costruttive e fonti di approvvigionamento a Leopoli-Cencelle. In E. De Minicis, C. Pavolini (Eds.), Risorse naturali e attività produttive: Ferento a confronto con altre realtà. Atti del II Convegno di Studi in memoria di Gabriella Maetzke (Viterbo, 27-28 aprile 2010) (pp. 299-340). Viterbo: Università della Tuscia.

Stasolla, F. R. (2012). Leopoli-Cencelle: il quartiere sud-orientale. Spoleto: Centro Italiano di Studi sull'Alto Medioevo.

Stasolla, F. R. (2012). Gli indicatori economici delle ceramiche. In Cortonesi, A., Esposito, A., Ermini Pani, L. (2007). Corneto medievale: territorio, società, economia, istituzioni religiose. Atti del convegno (Tarquinia, 24-25 novembre 2007) (pp. 151-167). Tarquinia: Società Tarquiniense di Arte e Storia.

Supino, P. (1969). La «Margarita Cornetana». Regesto dei documenti. Roma: Società Romana di Storia Patria.

Sweeney, D. (1995). Agriculture in the Middle Ages: Technology, Practice and Representation. Philadelphia: University of Pennsylvania Press.

Toti, O. (1992). Storia di Civitavecchia: dalle origini agli albori dell'età moderna. Civitavecchia: La Litografica.

Toti, O. (1993). Centocelle. Civitavecchia: Comune di Civitavecchia. 
Tramontana, S. (2000). Spazi, lavoro, semina: le tecniche di coltivazione e gli attrezzi agricoli nella Sicilia normanna. In G. Rossetti, G. Vitolo (Eds.), Medioevo, Mezzogiorno, Mediterraneo: studi in onore di Mario Del Treppo (pp. 43-62). Napoli: Liguori Editore.

Vallelonga, F. (2006). Decastellamento e trasformazioni territoriali nell'area dei Monti della Tolfa tra bassomedioevo ed età moderna. In R. Di Paola, A. Antoniutti, M. Gallo (Eds.), Enea Silvio Piccolomini. Arte, Storia e Cultura nell'Europa di Pio II. Atti dei Convegni Internazionali di Studi 2003-2004 (pp. 179-205). Roma: Libreria Editrice Vaticana.

Vallelonga, F. (2012). Insediamenti fortificati di età medievale in un territorio di confine: I'area dei Monti della Tolfa e la Valle del Mignone. In F. Cambi (Ed.), Il ruolo degli "oppida» e la difesa del territorio in Etruria: casi di studio $e$ prospettive di ricerca (pp. 173-221). Trento: Tangram Edizioni Scientifiche.

Vanni Desideri, A. (2009). Villaggi abbandonati e pievi tra guerre e pandemia: nota archeologica per la storia del castello di Cigoli nel Valdarno Pisano. Archeologia Medievale, 36, 227-236.

Vannini, G. (1985). Un villaggio di minatori e fonditori di metallo nella Toscana del medioevo: San Silvestro (Campiglia Marittima). Area 5000. Archeologia Medievale, 12, 363-371.

Velluti, G. (1993). Il frantoio di Rocca San Silvestro (Campiglia Marittima): appunti per la ricostruzione del ciclo dell'olio di oliva. I materiali. Archeologia Medievale, 20, 176-182.

Vigil-Escalera Guirado, A. (2013). Ver el silo medio lleno o medio vacío: la estructura arqueológica en su contexto. In A. Vigil-Escalera Guirado, G. Bianchi (Eds.), Horrea, barns and silos: Storage and incomes in early Medieval Europe (pp. 127-144). Bilbao: Universidad del País Vasco.

White, K. D. (1967). Agricultural Implements of the Roman World. Cambridge: University Press.

Zagari, F. (2012). I metalli. In F. R. Stasolla (Ed.), Leopoli-Cencelle: il quartiere sudorientale (pp. 252-273). Spoleto: Centro Italiano di Studi sull'Alto Medioevo.

Zifferero, A. (1996). Problemi di archeologia mineraria nel Lazio: il caso dei Monti della Tolfa. Archeologia Medievale, 23, 739-754. 